\title{
A Comparative Study of Working Capital Management of Steel Companies in India
}

\author{
Prof. (Dr.) K. K. Vyas ${ }^{1}$, Mrs. Rajani Bora ${ }^{2}$ \\ ${ }^{1}$ Associate Professor (Retired) Department of Accounting, JNV University, Jodhpur, India \\ ${ }^{2}$ Research Scholar, Department of BFE, JNV University, Jodhpur, India \\ Email: rajanibora08@gmail.com
}

\begin{abstract}
For an effectualness operating of a business concern, working capital plays a vital role as a life blood of organization. I even have created efforts during this paper to review the varied assets and liabilities elements to find out the outcome of working capital management policies on profit of BSE/ NSE listed steel corporations of India. This study is predicated on secondary information collected from annual reports of various steel corporations for the year 2009 to 2016. During the study of this paper I have used ratio analysis technique to investigate and interpret the data, to spot the considerable effects of current assets and current liabilities management on the profit. The management of assets is important because it may enforce an, on the spot impact on profit and liquidity. Within the study, six private and public sector steel corporations operative in India have been hand-picked.
\end{abstract}

Keywords-BSE, Current Assets, Current Liabilities, NSE, profit etc.

\section{INTRODUCTION}

The developing economies are typically faced with the matter of inefficient utilization of resources in the market. Capital is the scarcest productive resource in such economies and efficient utilization of these resources promotes the role of growth, cuts down the value of production and particularly improves the potency of the productivity system. Capital required by commercial enterprises is divided into 2 categories: one is fixed capital and the second is working/ functioning capital. Thus, fixed capital and working capital are the dominant contributors to the capital of a developing country. Fixe capital investment generates productive capability, whereas assets make the use of that capability potential and thereby to take care of the continuity of the cyclical flow of production and sales. Therefore, working capital /assets are understood as life blood of business. The earlier attention of financial management was a lot of on a protracted term financial decisions. Working capital management, that deals with short term financial decisions, seems to possess been comparatively neglected within the literature of finance. Leslie $\mathrm{R}$ Howard, justifiably points out that a deeper understanding of the importance of working capital and its satisfactory provisions will cause not solely a fabric saving within the economical use of capital, however conjointly assist in furthering the ultimately aim of business, particularly that of increasing financial outcome or return with the use of minimum quantity of resources.

A simple and enforced working capital management includes a vital role for firms' profitability also on sustains liquidity powers. The vital element of finance is functioning capital management; since it directly influences firm's profit also as liquidity in everyday activities. In any business concern, it's apparent that there should be spare assets to run day to day operation. Therefore, to perform the business activities swimmingly, working capital of firm's should be plenteous. it's obvious that, the importance of economical current assets and liabilities management is unquestionable to any or all business activities. Because, business capability depends on its ability to effectively use of current assets such as cash, inventories, and current liabilities such as creditors, bills payables etc.

Thus, working capital ought to neither too high nor too low. Excessive assets indicates an accumulation of idle current assets (resources) that don't contribute in generating financial gain (profit) for the firm throughout the operating period. On the opposite aspect, inadequate assets harm the creditors' trustworthiness of day to day activities of companies and this could cause financial breakdown (bankruptcy). 


\section{MEANING AND DEFINITION OF WORKING CAPITAL}

Working capital means subtraction of current liabilities from current assets. In accounting terminology, it is the difference between inflow and outflow of funds. Prof. $\mathrm{H}$. G. Guthmann and H. E. Dougall, point out working capital as the excess of current assets over current liabilities. Mayer J.N. define working capital as the amount of current assets that would remain in a firm if all its current liabilities are paid. L. N. Chopde, D. H. Choudhri \& Sandeep Chopde said "Working capital is descriptive of that capital which is not fixed but, the more common use of working capital is to common use of working capital is to consider it as the difference between the book value of the current assets and current liabilities."

In short, working capital is the difference between current assets and current liabilities. It suggests that if we've got one hundred fifty lacks current assets and one hundred lack current liabilities, the working capital is fifty lacks. Thus, working capital is the quantity of current assets that stay within the firm whereas firm's all liabilities are paid. It suggests that once working capital stays within the firm, firms don't have any liabilities to pay.

\section{OBJECTIVES OF ANALYSIS}

3.1 To establish a relationship between working capital Management and profitability during eight years from 2009 to 2016.

3.2 To make comparative study of financial ratios of six steel corporations of India.

\section{RESEARCH METHODOLOGY}

The Management of working capital is essential as it has a direct impact on profitability and liquidity. The study is based on secondary data collected which had been collected from annual reports of different steel companies for the period 2009 to 2016. With the help of Current ratio and Quick ratio. It can be interprets that the working capital management is an important aspect which is very crucial for the success of different steel companies. The following hypothesis are tested here for conclusion and findings-

$\mathbf{H}_{\mathbf{0}}$ : Current Ratio of Indian Iron \& Steel Companies does not differ significantly among the years.

$\mathbf{H}_{1}$ : Current Ratio differ significantly among the various Indian Iron \& Steel Companies over the years.

Ho : Quick Ratio of Indian Iron \& Steel Companies does not differ significantly among the years.

$\mathbf{H}_{2}$ : Quick Ratio differ significantly among the various Indian Iron \& Steel Companies over the years.

\section{ANALYSIS FOR STEEL COMPANIES IN INDIA}

\subsection{CURRENT RATIO}

Current assets divided by current liabilities gives the current ratio. Current liabilities means liabilities repayable within a year and current assets are the assets which are convertible and meant to be converted into cash within a year. An ideal current ratio is $2: 1$ which means that current assets should be at least twice the amount of current liabilities.

Current Ratio $=$ Current Assets $/$ Current Liabilities

Graph 1.1 Current Ratio

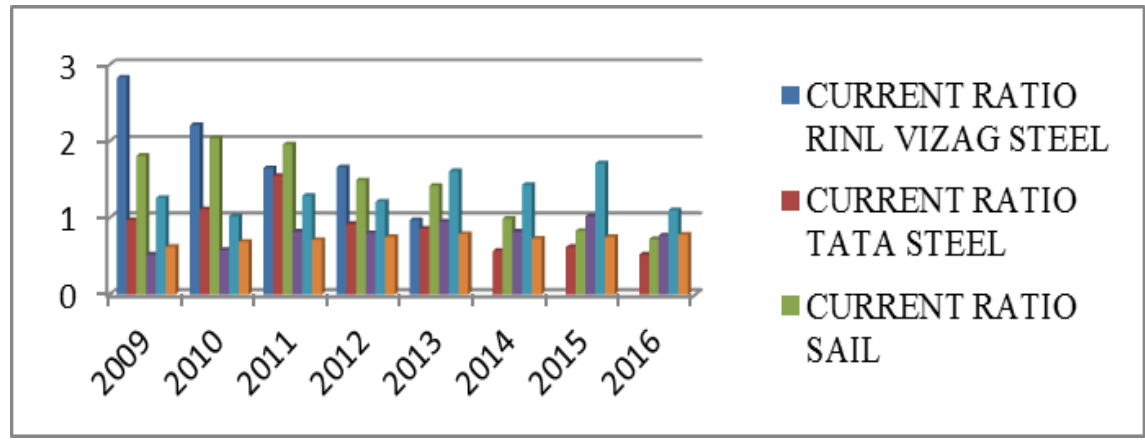


Table 1.1 Current Ratio

\begin{tabular}{|l|l|l|l|l|l|l|l|l|}
\hline & $\begin{array}{l}\text { March } \\
2009\end{array}$ & $\begin{array}{l}\text { March } \\
2010\end{array}$ & $\begin{array}{l}\text { March } \\
2011\end{array}$ & $\begin{array}{l}\text { March } \\
2012\end{array}$ & $\begin{array}{l}\text { March } \\
2013\end{array}$ & $\begin{array}{l}\text { March } \\
2014\end{array}$ & $\begin{array}{l}\text { March } \\
2015\end{array}$ & $\begin{array}{l}\text { March } \\
2016\end{array}$ \\
\hline RINL Vizag steel & 2.83 & 2.21 & 1.65 & 1.66 & 0.97 & - & - & - \\
\hline Tata steel & 0.97 & 1.11 & 1.55 & 0.92 & 0.86 & 0.57 & 0.62 & 0.52 \\
\hline SAIL & 1.81 & 2.04 & 1.96 & 1.49 & 1.42 & 0.99 & 0.83 & 0.72 \\
\hline JSW & 0.52 & 0.58 & 0.82 & 0.80 & 0.95 & 0.82 & 1.02 & 0.77 \\
\hline Jindal steel & 1.26 & 1.02 & 1.29 & 1.21 & 1.61 & 1.43 & 1.71 & 1.10 \\
\hline Surya Roshni & 0.62 & 0.69 & 0.71 & 0.75 & 0.79 & 0.73 & 0.75 & 0.78 \\
\hline
\end{tabular}

Table 1.2 : Report for mean and standard deviation

\begin{tabular}{|l|r|r|r|r|r|r|}
\hline & \multicolumn{1}{|c|}{ VAR1 } & \multicolumn{1}{|c|}{ VAR2 } & \multicolumn{1}{|c|}{ VAR3 } & \multicolumn{1}{|c|}{ VAR4 } & \multicolumn{1}{|c|}{ VAR5 } & \multicolumn{1}{|c|}{ VAR6 } \\
\hline Mean & 1.8640 & .8900 & 1.4075 & .7850 & 1.3288 & .7275 \\
\hline $\mathrm{N}$ & 5 & 8 & 8 & 8 & 8 & 8 \\
\hline Std. Deviation & .69633 & .33899 & .51475 & .16801 & .23985 & .05471 \\
\hline
\end{tabular}

Here

Var 1- RINL VIZAG STEEL

Var 2- TATA STEEL

Var 3- SAIL

Var 4- JSW

Var 5- JINDAL STEELS

Var 6- SURYA ROSHNI ltd.

\subsection{QUICK RATIO}

Quick ratio is the measure of the instant debt paying ability of the firm. Thus it is also known as Acid test ratio. This ratio establishes the relationship between quick assets and liquid liabilities. Quick ratio 0.50:1 is considered as an ideal ratio. If the quick ratio is $0.50: 1$, the financial position of the firm seems to be sound and good. On the other hand if the quick ratio is less than 0.50:1, the financial position of the firm is unsound.

Quick Ratio = Quick Assets/ Current Liabilities

Graph 2.1 Quick Ratio

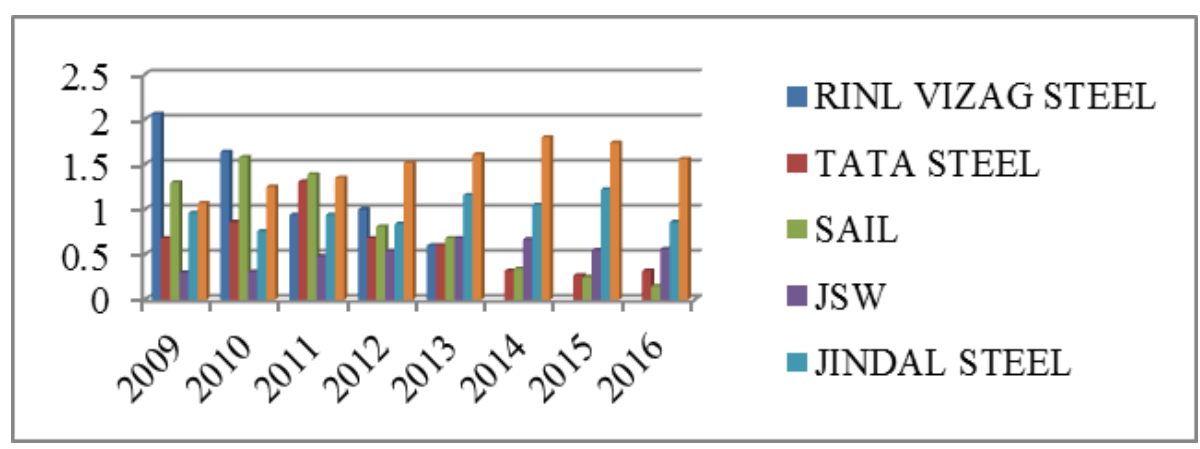


Table 2.1 Quick Ratio

\begin{tabular}{|l|l|l|l|l|l|l|l|l|}
\hline & $\begin{array}{l}\text { March } \\
2009\end{array}$ & $\begin{array}{l}\text { larch } \\
2010\end{array}$ & $\begin{array}{l}\text { March } \\
2011\end{array}$ & $\begin{array}{l}\text { March } \\
2012\end{array}$ & $\begin{array}{l}\text { March } \\
2013\end{array}$ & $\begin{array}{l}\text { March } \\
2014\end{array}$ & $\begin{array}{l}\text { March } \\
2015\end{array}$ & $\begin{array}{l}\text { March } \\
2016\end{array}$ \\
\hline RINLVizag steel & 2.06 & 1.64 & 0.94 & 1.00 & 0.60 & - & - & - \\
\hline Tata steel & 0.68 & 0.86 & 1.31 & 0.68 & 0.60 & 0.32 & 0.27 & 0.32 \\
\hline SAIL & 1.30 & 1.58 & 1.39 & 0.81 & 0.68 & 0.34 & 0.25 & 0.15 \\
\hline JSW & 0.30 & 0.31 & 0.48 & 0.54 & 0.68 & 0.67 & 0.55 & 0.56 \\
\hline Jindal steel & 0.96 & 0.76 & 0.94 & 0.84 & 1.16 & 1.05 & 1.22 & 0.86 \\
\hline Surya Roshni & 1.07 & 1.25 & 1.35 & 1.52 & 1.61 & 1.80 & 1.74 & 1.56 \\
\hline
\end{tabular}

Table 2.2 Report for mean and standard deviation for Quick Ratio

\begin{tabular}{|l|r|r|r|r|r|r|}
\hline & VAR00013 & \multicolumn{1}{|c|}{ VAR00014 } & VAR00015 & VAR00016 & VAR00017 & \multicolumn{1}{|c|}{ VAR00018 } \\
\hline Mean & 1.2480 & .6300 & .8125 & .5113 & .9738 & 1.4875 \\
\hline $\mathrm{N}$ & 5 & 8 & 8 & 8 & 8 & 8 \\
\hline Std. Deviation & .58934 & .34703 & .55502 & .14367 & .15991 & .24852 \\
\hline
\end{tabular}

\section{CONCLUSION}

It is observed from the above table 1.1 that the average current ratio (mean) of these steel companies are as follows- RINL (1.86), TATA (0.89), SAIL(1.41), JSW(0.79), Jindal steel (1.33) and Surya Roshni ltd. (0.73). This present study indicates good liquidity condition of RINL, SAIL and Jindal steel companies because the current ratio of these companies are more than 1 i.e. It represents that the companies can meet the shortterm liabilities at maturity without fail.

During this study it is also observed that the solvency condition of TATA, JSW and Surya Roshni ltd. Is not as good as their average current ratio is $>1$ i.e. it represents that these companies can not meet their short- term liabilities at maturity.

The standard deviation of current ratio for RINL (.69633), TATA (.33899), SAIL (.51475), JSW(.16801), Jindal steel (.23985) and Surya Roshni ltd. (.05471). The SD of current ratio of RINL, TATA and SAIL are greater than the industry average of 0.33544 indicating a large change during the study period. On the other hand the SD of current ratio of JSW, Jindal steel and Surya Roshni ltd. is less than industry average that indicates less inconsistency for the companies during the study period.

Thus, I accepted alternative hypothesis i.e. $\mathrm{H}_{1}$, Current Ratio differ significantly among the various Indian Iron \& Steel Companies over the years and rejected Null hypothesis i.e. $\mathrm{H}_{0}$ Current Ratio of Indian Iron \& Steel Companies does not differ significantly among the years.

ISSN: 2456-7620
A quick ratio which is greater than 1 means that the company has sufficient quick assets to pay for its current liabilities. These Quick assets (cash and cash equivalents, marketable securities, and short-term receivables) are current assets that can be converted into cash very easily. Thus, companies having good quick ratios are favored by creditors.

In the above table 2.1 , the average quick ratio of RINL with 1.2480 and Surya Roshni Ltd. with 1.4875 shows that these Companies have enough current assets to cover their current liabilities. For every Rs.1 of current liability, the company has Rs. 1.24 and 1.48 of quick assets respectively to pay for it.

The average quick ratio of TATA with 0.6300 , SAIL with 0.8125 , JSW with 0.5113 and JINDAL Steel with 0.9738 shows that these companies have not sufficient current assets to cover their current liabilities during this study period.

The ideal quick ratio depends greatly upon the industry that the company is working in. A company which is operating in an industry with a short operating cycle generally does not need a high quick ratio. Financial ratios should be compared with industry standards to determine whether such ratios are normal or deviate materially from what is expected.

As shown in the table 2.2 the standard deviation of Quick ratio for RINL (0.58934), TATA (0.34703), SAIL (0.55502), JSW (0.14367), Jindal steel(0.15991) and Surya Roshni ltd. (0.24852). The SD of Quick ratio of 
RINL, TATA, and SAIL are greater than or equal to the industry average of 0.34 indicating a large change during the study period. On the other hand the SD of quick ratio of JSW, Surya Roshni ltd. and Jindal steel is less than industry average that indicates less consistency for the companies during the study period.

Thus, I accepted Alternate hypothesis i.e. $\mathrm{H}_{2}$, Quick Ratio differ significantly among the various Indian Iron \& Steel Companies over the years and rejected Null hypothesis i.e. $\mathrm{H}_{0}$, Quick Ratio of Indian Iron \& Steel Companies does not differ significantly among the years.

\section{REFERENCES}

[1] Pandey I M (2003), Financial Management, Vikas Publishing House Pvt. Ltd., New Delhi

[2] BhuniaAmalendu (2011) Short term Liquidity management -A study of Indian Steel companies, iij, vol -II, Issue -4, issn no.2229-5674 pp (152)

[3] Iran World Applied Sciences Journal 12 (7): pp (1093, 1099)

[4] https://www.tatasteel.com, Annual Report

[5] https://www.sail.co.in, Annual Report

[6] https://www.jindalsteelpower.com, Annual Report

[7] https://www.vizagsteel.com, Annual Report

[8] https://www.surya.co.in, Annual Report

[9] Khan and Jain (2004), Financial Management, fourth Edition, Tata McGraw Hill Publishing Company, New Delhi.

[10] Prasanna Chandra, Financial Management - Theory and Practice, 4th Edition, Tata McGraw Hill Publishing Company Limited, New Delhi. 